\section{Shelf life of fresh air packaged and precooked vacuum pack- aged quails}

\author{
Francesca Piras, ${ }^{1}$ Roberta Mazza, ${ }^{1}$ \\ Simonetta G. Consolati, ${ }^{1}$ \\ Giuseppe Cannas, ${ }^{2}$ Daniele Casti, \\ Gianluca Busia, ${ }^{1}$ Rina Mazzette ${ }^{1}$ \\ 'Settore di Ispezione degli Alimenti di \\ Origine Animale, Dipartimento di \\ Medicina Veterinaria, Università di \\ Sassari, Sassari; ${ }^{2}$ Azienda Sanitaria \\ Locale n. 4, Lanusei (OG), Italy
}

\section{Abstract}

The shelf-life of 3 batches (Q1, Q2, Q3) of quail meat, were examined. Q1 were cut and seasoned with commercial olive oil, stoned green olive and sliced bacon. Q2 were divided into two subgroups: Q2.1 produced in the previously described conditions; Q2.2 seasoned also with rosemary. Quails were placed in lowdensity polystirene barrier trays and aerobically packaged. Q3 quails were boiled in salted hot water for $40 \mathrm{~min}$, seasoned with myrtle leafs, placed in low density polyethylene bags and vacuum packaged. All samples were stored at +2 and $+7^{\circ} \mathrm{C}$. Analysis were conducted at 0,3 , 7, 9 and 14 days (T0, T3, T7, T9, and T14, respectively). For all the samples, $\mathrm{pH}$ measurement and microbial analysis [total viable count (TVC), Enterobacteriaceae, E. coli, Lactobacillus spp. (LAB), Pseudomonas spp., Brochothrix thermosphacta, coagulase-negative Staphylococci (CNS), Enterococcus spp., yeasts and moulds, Salmonella spp., Listeria monocytogenes] were performed. Initial TVC levels of fresh quails ( $c a .4 \log \mathrm{CFU} / \mathrm{g}$ ) were rather high and this may be due to the microbial population of the raw material. In $\mathrm{Q} 1$ and Q2.1 samples, TVC reached the value of $7 \mathrm{log}$, which is considered as the upper acceptability limit for fresh poultry meat (after T9 under storage at $+2^{\circ} \mathrm{C}$ and after $\mathrm{T} 7$ at $+7^{\circ} \mathrm{C}$ ). In $\mathrm{Q} 2.2$ samples such limit was reached earlier, after T3. In Q3 samples, lower TVC levels were recorded and did not reach the above mentioned limit, not even at the end of storage. However, mean counts $>5$ log were reached, maybe because of a post-cooking cross-contamination. Salmonella spp. prevalence was $33 \%$ in Q1, Q2.1 and Q2.2 samples.

\section{Introduction}

In the last years poultry meat has become increasingly popular worldwide due to its low cost of production, high nutritional quality, low fat content and low cholesterol level (Mexis et al., 2012). For the same reasons, the consumption of game bird meat has gained increasing favour among consumers and typical game bird species such as quail (Coturnix coturnix), pheasant (Phasianus colchicus), and partridge (Alectoris spp.), are being produced in alternative poultry farms (Rojas et al., 2009).

However, there is still a lack of data about microbial profile and shelf-life of meat products and meat preparations obtained from farm animals of these species, while some informations are available on hunted animals and a comparison can be done with analogue poultry products.

Poultry products is highly perishable food providing an almost perfect medium for microbial growth, including both spoilage and pathogenic microorganisms which represent a potential health hazard (Khanjari et al., 2013). Microbial conditions of poultry meat will depend mainly on the initial bacterial load and the microbial species carried on the skin, in the gastro-intestinal tract or in the muscle, which are influenced by farm practices and, most of all, by slaughtering procedures (Mexis et al., 2012). During slaughtering, carcass microflora increases progressively and there is a change in the microbial population which, in the living animals, is mainly represented by Gram positive bacteria. Subsequently, in the carcasses, these microrganisms are replaced by Gram negative species, as Pseudomonas spp., Enterobacteriaceae and Acinetobacter spp., wich are psychrotrophic and able to grow at refrigeration temperatures and to cause spoilage (Scarano et al., 2004). Poultry-based meat products and meat preparations are sold as either fresh or precooked, and after packaging they are usually stored under refrigeration (Patsias et al., 2008). Moreover, nowadays the distance between processing plants and retail distribution has become increasingly longer than in the past, because of the greater demands by retailers and consumers for retail products with longer shelf-life. For this reason, shelf-life of chicken and chicken products must be optimised to meet all marketing requirements.

The aim of the study was to determine the shelf-life of fresh air-packaged quails and precooked vacuum-packaged quails.

\section{Materials and Methods}

Samples obtained from 3 batches (Q1, Q2 and Q3) of quail meat were examined. All the quails were slaughtered in an avian slaughterhouse placed in Sardinia. The slaughtered quails were immediately chilled to a $\mathrm{T}<4^{\circ} \mathrm{C}$ and
Correspondence: Francesca Piras, Settore di Ispezione degli Alimenti di Origine Animale, Dipartimento di Medicina Veterinaria, Università di Sassari, via Vienna 2, 07100 Sassari.

Tel. +39.079.229447 - Fax: +39.079.229458.

E-mail: fpiras@uniss.it

Key words: Shelf-life, Quails, Fresh, Precooked, Package.

Conflict of interests: the authors declare no potential conflict of interests.

Aknowledgments: we aknowledge La Quaglia Sarda, Villagrande Strisaili (OG), Italy.

Received for publication: 12 May 2013

Revision received: 24 July 2013.

Accepted for publication: 24 July 2013.

This work is licensed under a Creative Commons Attribution 3.0 License (by-nc 3.0).

(C) Copyright F. Piras et al., 2013

Licensee PAGEPress, Italy

Italian Journal of Food Safety 2013; 2:e45

doi:10.4081/ijfs.2013.e45

then transported, under controlled conditions, to the meat processing plant.

\section{Shelf-life studies}

Quails from Q1 were cut and seasoned with commercial olive oil, stoned green olive and sliced bacon. Quails from Q2 were divided into two subgroups: one (Q2.1) was produced in the previously described conditions; the other (Q2.2) was seasoned also with rosemary (Rosmarinus officinalis). The rosemary was previously treated with a $1 \%$ solution of sodium hypochlorite. Quails were placed in low-density polystirene barrier trays (two quails/tray), $75 \mu \mathrm{m}$ in thickness having an oxygen permeability of $3800 \mathrm{~cm}^{3} / \mathrm{m}^{2} / 24 \mathrm{~h} / 1$ bar and a water vapour permeability of $150 \mathrm{~g} / \mathrm{m}^{2}$ day at $90 \%$ relative humidity $(\mathrm{RH}) / 38^{\circ} \mathrm{C}$, chilled with an air-chiller to a $\mathrm{T}<4^{\circ} \mathrm{C}$ and then aerobically packaged.

Quails from Q3 were prepared as a traditional Sardinian recipe, known as grive. Quails were boiled in salted hot water for $40 \mathrm{~min}$ and, afterwards, seasoned with myrtle (Myrtus communis) leafs, previously treated with a mixture of water and sodium bicarbonate. Afterwards, quails were placed in low density polyethylene bags ( 2 quails/bag) with an oxygen permeability of $52.2 \mathrm{~mL} / \mathrm{m}^{2}$ day atm at $60 \%$ $\mathrm{RH} / 25^{\circ} \mathrm{C}$ and water vapour permeability of 2.4 $\mathrm{g} / \mathrm{m}^{2}$ day at $100 \% \mathrm{RH} / 25^{\circ} \mathrm{C}$.

Samples coming from the three batches were divided into two groups and stored in the dark at two temperatures: $+2 \pm 2{ }^{\circ} \mathrm{C}$ (ideal retail condition storage) and $+7 \pm 2^{\circ} \mathrm{C}$ (simulating a temperature abuse condition). During the storage period, the temperature was monitored by 
datalogger (Tynitag Plus; Tynitag, Chichester, UK).

Sampling and analysis were conducted at the following intervals: 0 (T0), 3 (T3), 7 (T7), 9 (T9) and 14 (T14) days. Overall, 72 samples were analysed: 36 fresh quail preparations airpackaged without rosemary $(\mathrm{Q} 1, \mathrm{Q} 2.1) ; 18$ fresh quail preparations air-packaged with rosemary $(\mathrm{Q} 2.2)$; 18 precooked quail vacuumpackaged (Q3). Prior to lab analysis, the following organoleptic characteristics of the packaged samples were evaluated: i) package collapse; ii) drip loss; iii) meat colour.

\section{Chemical analysis}

Samples (10 g) were homogenised with distilled water (1:1) and the homogenate was used for $\mathrm{pH}$ determination with a $\mathrm{pH}$-meter (Orion 420; Columbia Weather Systems Inc., Hillsboro, OR, USA).

\section{Microbial analysis}

All the samples were analysed for total viable count (TVC) (ISO 4833; ISO, 2013); Enterobacteriaceae (ISO 21528-2; ISO, 2004) and $E$. coli (ISO 16649; ISO, 2001); Lactobacillus spp. (LAB) count on Man Rogosa Sharpe medium Agar (Oxoid, Basingstoke, UK); Pseudomonas spp. count on Pseudomonas Agar Base (0xoid); Brochothrix thermosphacta count on streptomycin Sulphate-Thallous Acetate-cycloheximide (actidione) Agar (Oxoid); coagulase negative Staphylococci (CNS) count on Mannitol Salt Agar (Oxoid); Enterococcus spp. count on Kanamycin Aesculin Azide Agar (Oxoid) base with; yeasts and moulds count on Oxytetracycline Agar Base (Oxoid); Salmonella spp. (ISO 6579/2002; ISO, 2002); Listeria monocytogenes (ISO 11290-1:1996 and 11290-2:1998; ISO, 1996, 1998).

For the isolation of Salmonella, the ISO method 6579/2002 (ISO, 2002) was used. Presumptive colonies were submitted to phenotypic identification with the API ID $32 \mathrm{E}$ system (bioMérieux, Marcy l'Etoile, France). Fifteen isolates were sent to the laboratories of the Centro Nazionale di Referenza per le salmonellosi in Legnaro (Padua, Italy), serotyped by agglutination tests with specific $\mathrm{O}$ and $\mathrm{H}$ antisera (Staten Serum Institute, Copenhagen, Denmark) and classified according to the Kauffmann-White scheme. Strains of serotypes Typhimurium and Enteritidis were phage typed according to the recommendations of the Health Protection Agency, London, UK. Moreover, precooked vacuum packaged quails were analysed for sulfite-reducing Clostridia on Perfringens agar base (Biolife, Bothell, WA, USA); Clostridium perfringens on Perfringens Agar Base (Biolife), and mesophilic aerobic sporulating bacteria on Tryptone Glucose Extract Agar (Oxoid). An analysis of variance (ANOVA) using the General Linear Model (GLM) procedure was performed for all considered variables, and when $\mathrm{F}$-values were significant at the $\mathrm{P}<0.05$ level, mean differences were separated by the least significant differences (LSD).

\section{Results}

\section{Organoleptic characteristics of the samples}

Fresh air-packaged quails (Q1, Q2.1, Q2.2): no collapse or drip loss were recorded during storage. The main odour throughout the entire storage time was ascribed to vegetal seasonings, particularly green olive in Q1 and Q2.1, samples and rosemary in Q2.2.

In samples stored at $+2^{\circ} \mathrm{C}$ meat colour was dark brilliant red until $\mathrm{T} 9$ and, only at the end of storage, darkening of the muscle surface was recorded. Moreover, at the end of storage slime was detected both on skin and muscle surface. In samples stored at $+7^{\circ} \mathrm{C}$ darkening of the muscle surface was recorded starting from $\mathrm{T} 9$ and become more evident at the end of storage irrespective of the temperatures.

Precooked quails under vacuum (Q3): meat colour remained unchanged and no slime was detected throughout the entire storage period. The main odour was that of myrtle until T9, whereas at the end of storage a moderate offodour was registered.

\section{$\mathrm{pH}$ analysis}

Table 1 shows the $\mathrm{pH}$ evolution during storage of fresh quails air-packaged with rosemary, fresh quail air-packaged without rosemary and precooked quails [mean \pm standard deviation (SD)].

Changes in $\mathrm{pH}$ during storage of Q1, Q2.1, Q2.2 samples were not statistically significant $(\mathrm{P}>0.05)$. Initial $\mathrm{pH}$ values were similar in $\mathrm{Q} 1$, Q1.2 (6.23 \pm 0.10$)$ and Q2.2 (6.15 \pm 0.08$)$. A similar trend was also noticed during storage with an increase of the mean values. Final $\mathrm{pH}$ levels were $6.16 \pm 0.23$ and $6.18 \pm 0.16$, respectively in samples stored at +2 and at $+7^{\circ} \mathrm{C}$.

As expected, higher mean $\mathrm{pH}$ levels were recorded in Q3 samples. T0 mean levels were $6.31 \pm 0.03$. A rise of the mean values were recorded during the storage, irrespective of the temperatures. T14 levels were $6.73 \pm 0.03$ and $6.67 \pm 0.14$, respectively in samples stored at +2 and at $+7^{\circ} \mathrm{C}$.

\section{Microbial analysis}

Tables 2, 3 and 4 show the results of the counts of the targeted microbial groups in fresh quails air-packaged with rosemary, fresh quail air-packaged without rosemary and precooked quails $\left(\log _{10} \mathrm{CFU} / \mathrm{g}\right.$; mean $\pm \mathrm{SD}$ ).

\section{Fresh quails air-packaged without and with rosemary (Q1, Q2.1, Q2.2)}

In the samples without rosemary $(\mathrm{Q} 1, \mathrm{Q} 2.1)$ stored at $+2^{\circ} \mathrm{C}$, initial mean values (T0) of TVC were $c a .3 \log$ and increased progressively $(\mathrm{P}<0.01)$ during storage, attaining a final level $>8 \log$. A similar trend was detected in samples stored at $+7^{\circ} \mathrm{C}$, for which higher counts were recorded throughout the entire storage period. In the samples seasoned with rosemary (Q2.2), initial levels were slightly higher (>4 log), compared to Q1 and Q2.1, with a progressive increase irrespective to temperatures. Final counts were $>8$ and $>9$ $\log$, respectively in samples stored at +2 and at $+7^{\circ} \mathrm{C}$.

Mean levels of Enterobacteriaceae in Q1 and Q2.1 samples stored at $+2^{\circ} \mathrm{C}$ showed a moderate increase and remained low, attaining a final level of $c a .3$ log. On the contrary, in samples

Table 1. pH evolution of fresh quails air-packaged with and without rosemary and precooked vacuum packaged quails.

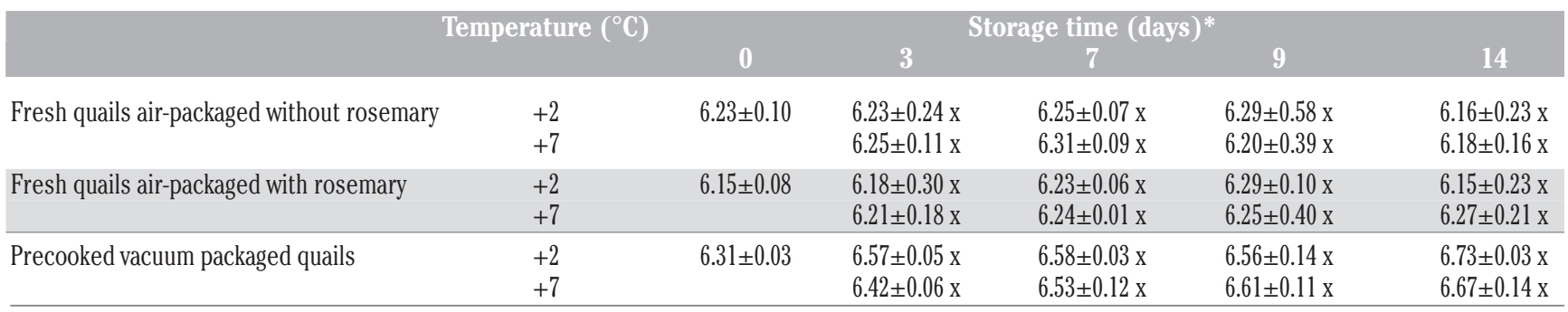

\footnotetext{
*Values are expressed as means \pm standard deviation. Means within columns with different capital letters $(\mathrm{X}$ and $\mathrm{Y})$ are significantly different $(\mathrm{P}<0.01 ; \mathrm{P}<0.5)$.
} 
Table 2. Changes in microbial profile (mean $\pm \mathrm{SD} ; \log \mathrm{CFU} / \mathrm{g}$ ) of fresh quails air-packaged without rosemary.

\begin{tabular}{|c|c|c|c|c|c|c|}
\hline \multirow[t]{2}{*}{ Microbial parameters } & \multirow[t]{2}{*}{ Temperature $\left({ }^{\circ} \mathrm{C}\right)$} & \multicolumn{5}{|c|}{ Storage time (days)* ${ }^{\circ}$} \\
\hline & & 0 & 3 & 7 & 9 & 14 \\
\hline TVC & $\begin{array}{l}+2 \\
+7\end{array}$ & $3.86 \pm 0.16$ & $\begin{array}{l}4.90 \pm 0.94 \mathrm{D}, \mathrm{x} \\
5.52 \pm 0.75 \mathrm{C}, \mathrm{x}\end{array}$ & $\begin{array}{l}7.50 \pm 0.56 \mathrm{C}, \mathrm{x} \\
6.66 \pm 0.75 \mathrm{~B}, \mathrm{x}\end{array}$ & $\begin{array}{l}6.17 \pm 0.86 \mathrm{~B}, \mathrm{x} \\
7.38 \pm 0.86 \mathrm{~B}, \mathrm{x}\end{array}$ & $\begin{array}{l}8.76 \pm 0.27 \mathrm{~A}, \mathrm{x} \\
8.94 \pm 0.18 \mathrm{~A}, \mathrm{x}\end{array}$ \\
\hline Enterobacteriaceae & $\begin{array}{l}+2 \\
+7\end{array}$ & $2.02 \pm 0.65$ & $\begin{array}{l}0.89 \pm 1.03 \mathrm{C}, \mathrm{x} \\
2.21 \pm 1.45 \mathrm{~B}, \mathrm{x}\end{array}$ & $\begin{array}{c}2.51 \pm 0.95 \mathrm{BA}, \mathrm{x} \\
3.68 \pm 0.29 \mathrm{~B}, \mathrm{x}\end{array}$ & $\begin{array}{c}2.68 \pm 0.43 \mathrm{BA}, \mathrm{y} \\
5.34 \pm 0.90 \mathrm{~A}, \mathrm{x}\end{array}$ & $\begin{array}{l}3.70 \pm 1.54 \mathrm{~A}, \mathrm{x} \\
5.65 \pm 1.04 \mathrm{~A}, \mathrm{x}\end{array}$ \\
\hline LAB & $\begin{array}{l}+2 \\
+7\end{array}$ & $2.20 \pm 0.12$ & $\begin{array}{l}2.90 \pm 0.51 \mathrm{~A}, \mathrm{x} \\
3.20 \pm 0.03 \mathrm{~B}, \mathrm{x}\end{array}$ & $\begin{array}{l}3.07 \pm 0.23 \mathrm{~A}, \mathrm{x} \\
3.37 \pm 0.08 \mathrm{~B}, \mathrm{x}\end{array}$ & $\begin{array}{l}3.06 \pm 0.65 \mathrm{~A}, \mathrm{x} \\
3.24 \pm 0.77 \mathrm{~B}, \mathrm{x}\end{array}$ & $\begin{array}{l}4.14 \pm 0.01 \mathrm{~A}, \mathrm{x} \\
4.21 \pm 0.02 \mathrm{~A}, \mathrm{x}\end{array}$ \\
\hline Pseudomonas spp. & $\begin{array}{l}+2 \\
+7\end{array}$ & $3.56 \pm 0.40$ & $\begin{array}{l}3.41 \pm 0.17 \mathrm{C}, \mathrm{x} \\
4.19 \pm 0.64 \mathrm{C}, \mathrm{x}\end{array}$ & $\begin{array}{l}5.22 \pm 1.32 \mathrm{~B}, \mathrm{x} \\
6.21 \pm 0.85 \mathrm{~B}, \mathrm{x}\end{array}$ & $\begin{array}{l}7.23 \pm 0.82 \mathrm{~A}, \mathrm{x} \\
7.90 \pm 1.06 \mathrm{~A}, \mathrm{x}\end{array}$ & $\begin{array}{l}7.95 \pm 0.43 \mathrm{~A}, \mathrm{x} \\
8.42 \pm 0.90 \mathrm{~A}, \mathrm{x}\end{array}$ \\
\hline CNS & $\begin{array}{l}+2 \\
+7\end{array}$ & $3.70 \pm 0.47$ & $\begin{array}{l}3.33 \pm 1.75 \mathrm{C}, \mathrm{x} \\
2.91 \pm 0.51 \mathrm{C}, \mathrm{x}\end{array}$ & $\begin{array}{c}4.33 \pm 0.71 \mathrm{BA}, \mathrm{y} \\
5.52 \pm 0.40 \mathrm{~B}, \mathrm{x}\end{array}$ & $\begin{array}{l}4.89 \pm 0.95 \mathrm{~B}, \mathrm{x} \\
5.58 \pm 0.23 \mathrm{~B}, \mathrm{x}\end{array}$ & $\begin{array}{l}6.21 \pm 1.26 \mathrm{~A}, \mathrm{x} \\
6.81 \pm 0.86 \mathrm{~A}, \mathrm{x}\end{array}$ \\
\hline Yeasts & $\begin{array}{l}+2 \\
+7\end{array}$ & $3.08 \pm 0.15$ & $\begin{array}{l}4.38 \pm 0.47 \mathrm{C}, \mathrm{x} \\
4.04 \pm 1.07 \mathrm{C}, \mathrm{x}\end{array}$ & $\begin{array}{l}5.08 \pm 0.57 \mathrm{~B}, \mathrm{y} \\
5.93 \pm 0.22 \mathrm{~B}, \mathrm{x}\end{array}$ & $\begin{array}{c}5.31 \pm 0.38 \mathrm{~B}, \mathrm{x} \\
5.640 .19 \mathrm{~B}, \mathrm{x}\end{array}$ & $\begin{array}{l}6.52 \pm 0.56 \mathrm{~A}, \mathrm{x} \\
7.20 \pm 0.28 \mathrm{~A}, \mathrm{x}\end{array}$ \\
\hline Moulds & $\begin{array}{l}+2 \\
+7\end{array}$ & $2.18 \pm 0.21$ & $\begin{array}{c}2.83 \pm 0.57 \mathrm{~A}, \mathrm{x} \\
3.33 \pm 0.19 \mathrm{x}\end{array}$ & $\begin{array}{c}2.50 \pm 0.53 \mathrm{~A}, \mathrm{x} \\
1.92 \pm 1.35 \mathrm{x}\end{array}$ & $\underset{-\sharp}{2.41 \pm 1.61 \mathrm{~A}}$ & $\underset{-\#}{3.51 \pm 2.60 \mathrm{~A}}$ \\
\hline
\end{tabular}

TVC, total viable count; LAB, Lactobacillus spp.; CNS, coagulase negative staphylococci. *Means in rows with different capital case letters (A-D) are significantly different (P<0.01); ${ }^{\circ}$ means within columns with different lower case letters $(\mathrm{x}$ and $\mathrm{y})$ are significantly different $(\mathrm{P}<0.01 ; \mathrm{P}<0.5) ;{ }^{n}$ not detected.

Table 3. Changes in microbial profile $($ mean $\pm S D ; \log \mathrm{CFU} / \mathrm{g})$ of fresh quails air-packaged with rosemary.

\begin{tabular}{|c|c|c|c|c|c|c|}
\hline Microbial parameters & Temperature $\left({ }^{\circ} \mathrm{C}\right)$ & & & age time (days & & \\
\hline & & 0 & 3 & 7 & 9 & 14 \\
\hline TVC & $\begin{array}{l}+2 \\
+7\end{array}$ & $4.50 \pm 0.81$ & $\begin{array}{l}4.33 \pm 0.61 \mathrm{C}, \mathrm{x} \\
5.75 \pm 1.53 \mathrm{C}, \mathrm{x}\end{array}$ & $\begin{array}{l}7.27 \pm 0.01 \mathrm{~B}, \mathrm{x} \\
7.48 \pm 0.01 \mathrm{~B}, \mathrm{y}\end{array}$ & $\begin{array}{l}8.28 \pm 0.08 \mathrm{BA}, \mathrm{x} \\
8.49 \pm 0.13 \mathrm{BA}, \mathrm{x}\end{array}$ & $\begin{array}{l}8.93 \pm 0.20 \mathrm{~A}, \mathrm{x} \\
9.56 \pm 0.27 \mathrm{~A}, \mathrm{x}\end{array}$ \\
\hline Enterobacteriaceae & $\begin{array}{l}+2 \\
+7\end{array}$ & $1.45 \pm 0.21$ & $\begin{array}{c}1.65 \pm 0.49 \mathrm{CB}, \mathrm{x} \\
2.09 \pm 0.35 \mathrm{~B}, \mathrm{x}\end{array}$ & $\begin{array}{l}3.12 \pm 0.93 \mathrm{BA}, \mathrm{x} \\
5.05 \pm 0.27 \mathrm{BA}, \mathrm{x}\end{array}$ & $\begin{array}{c}3.53 \pm 0.14 \mathrm{~A}, \mathrm{x} \\
5.12 \pm 1.32 \mathrm{BA}, \mathrm{x}\end{array}$ & $\begin{array}{l}4.21 \pm 0.75 \mathrm{~A}, \mathrm{x} \\
5.48 \pm 1.84 \mathrm{~A}, \mathrm{x}\end{array}$ \\
\hline LAB & $\begin{array}{l}+2 \\
+7\end{array}$ & $2.24 \pm 0.20$ & $\begin{array}{l}2.75 \pm 0.05 \mathrm{~A}, \mathrm{x} \\
2.77 \pm 0.05 \mathrm{D}, \mathrm{x}\end{array}$ & $\begin{array}{l}3.02 \pm 0.03 \mathrm{~A}, \mathrm{x} \\
2.94 \pm 0.02 \mathrm{C}, \mathrm{x}\end{array}$ & $\begin{array}{l}3.33 \pm 0.00 \mathrm{~A}, \mathrm{x} \\
3.26 \pm 0.10 \mathrm{~B}, \mathrm{x}\end{array}$ & $\begin{array}{l}3.34 \pm 0.06 \mathrm{~A}, \mathrm{x} \\
3.50 \pm 0.10 \mathrm{~A}, \mathrm{x}\end{array}$ \\
\hline Pseudomonas spp. & $\begin{array}{l}+2 \\
+7 \\
\end{array}$ & $3.74 \pm 0.06$ & $\begin{array}{l}3.72 \pm 0.24 \mathrm{C}, \mathrm{x} \\
3.94 \pm 0.34 \mathrm{D}, \mathrm{x}\end{array}$ & $\begin{array}{l}6.87 \pm 0.40 \mathrm{~B}, \mathrm{x} \\
6.48 \pm 0.01 \mathrm{C}, \mathrm{x}\end{array}$ & $\begin{array}{l}8.16 \pm 0.12 \mathrm{~A}, \mathrm{x} \\
8.35 \pm 0.23 \mathrm{~A}, \mathrm{x}\end{array}$ & $\begin{array}{l}7.87 \pm 0.17 \mathrm{~A}, \mathrm{x} \\
7.48 \pm 0.01 \mathrm{~B}, \mathrm{x}\end{array}$ \\
\hline CNS & $\begin{array}{l}+2 \\
+7\end{array}$ & $4.30 \pm 0.68$ & $\begin{array}{l}0.86 \pm 1.22 \mathrm{C}, \mathrm{x} \\
1.76 \pm 0.04 \mathrm{C}, \mathrm{x}\end{array}$ & $\begin{array}{l}4.39 \pm 0.44 \mathrm{~B}, \mathrm{x} \\
5.22 \pm 0.98 \mathrm{~B}, \mathrm{x}\end{array}$ & $\begin{array}{l}5.47 \pm 0.58 \mathrm{BA}, \mathrm{x} \\
5.93 \pm 0.64 \mathrm{BA}, \mathrm{x}\end{array}$ & $\begin{array}{l}6.85 \pm 0.64 \mathrm{~A}, \mathrm{x} \\
7.57 \pm 0.33 \mathrm{~A}, \mathrm{x}\end{array}$ \\
\hline Yeasts & $\begin{array}{l}+2 \\
+7\end{array}$ & $3.60 \pm 0.02$ & $\begin{array}{l}3.22 \pm 0.88 \mathrm{D}, \mathrm{x} \\
3.78 \pm 0.43 \mathrm{C}, \mathrm{x}\end{array}$ & $\begin{array}{c}4.96 \pm 0.73 \mathrm{CB}, \mathrm{x} \\
5.21 \pm 0.07 \mathrm{~B}, \mathrm{x}\end{array}$ & $\begin{array}{c}5.30 \pm 0.19 \mathrm{BA}, \mathrm{x} \\
5.87 \pm 0.27 \mathrm{~B}, \mathrm{x}\end{array}$ & $\begin{array}{l}6.46 \pm 0.29 \mathrm{~A}, \mathrm{x} \\
7.16 \pm 0.01 \mathrm{~A}, \mathrm{x}\end{array}$ \\
\hline Moulds & $\begin{array}{l}+2 \\
+7\end{array}$ & $2.65 \pm 0.07$ & $\begin{array}{c}2.69 \pm 0.44 \mathrm{BA}, \mathrm{x} \\
3.00 \pm 0.01 \mathrm{~A}, \mathrm{x}\end{array}$ & $\begin{array}{l}2.89 \pm 0.58 \mathrm{~A}, \mathrm{x} \\
3.55 \pm 0.07 \mathrm{~A}, \mathrm{x}\end{array}$ & $\begin{array}{l}-\# \\
-\#\end{array}$ & $\begin{array}{c}-\# \\
4.98 \pm 0.03 \mathrm{~A}\end{array}$ \\
\hline
\end{tabular}

TVC, total viable count; LAB, Lactobacillus spp.; CNS, coagulase negative staphylococci. * ${ }^{M}$ Means in rows with different capital case letters (A-D) are significantly different $(\mathrm{P}<0.01) ;{ }^{\circ}$ means within columns with different lower case letters ( $\mathrm{x}$ and $\mathrm{y})$ are significantly different $(\mathrm{P}<0.01 ; \mathrm{P}<0.5)$; \#not detected.

Table 4. Changes in microbial profile (mean $\pm S D$; $\log \mathrm{CFU} / \mathrm{g})$ of precooked vacuum packaged quails.

\begin{tabular}{|c|c|c|c|c|c|c|}
\hline \multirow[t]{2}{*}{ Microbial parameters } & \multirow[t]{2}{*}{ Temperature $\left({ }^{\circ} \mathrm{C}\right)$} & \multicolumn{5}{|c|}{ Storage time (days)* ${ }^{\circ}$} \\
\hline & & 0 & 3 & 7 & 9 & 14 \\
\hline TVC & $\begin{array}{l}+2 \\
+7\end{array}$ & $2.28 \pm 0.14 \mathrm{C}$ & $\begin{array}{l}3.07 \pm 0.11 \mathrm{~B}, \mathrm{x} \\
1.65 \pm 0.07 \mathrm{D}, \mathrm{y}\end{array}$ & $\begin{array}{c}5.0 \pm 0.05 \mathrm{~A}, \mathrm{x} \\
4.42 \pm 0.11 \mathrm{C}, \mathrm{y}\end{array}$ & $\begin{array}{l}3.48 \pm 0.01 \mathrm{~B}, \mathrm{x} \\
5.71 \pm 0.20 \mathrm{~B}, \mathrm{x}\end{array}$ & $\begin{array}{l}5.39 \pm 0.46 \mathrm{~A}, \mathrm{x} \\
6.43 \pm 0.16 \mathrm{~A}, \mathrm{x}\end{array}$ \\
\hline Enterobacteriaceae & $\begin{array}{l}+2 \\
+7\end{array}$ & $-\#$ & $\begin{array}{l}- \\
-\end{array}$ & $\begin{array}{l}- \\
-\end{array}$ & $\begin{array}{l}- \\
-\end{array}$ & $\begin{array}{c}- \\
2.13 \pm 0.49\end{array}$ \\
\hline Pseudomonas spp. & $\begin{array}{l}+2 \\
+7\end{array}$ & - & $\begin{array}{l}- \\
-\end{array}$ & $\begin{array}{c}4.09 \pm 0.19 \\
-\end{array}$ & $\begin{array}{l}3.07 \pm 0.41 \\
4.55 \pm 0.49\end{array}$ & $\begin{array}{l}5.66 \pm 0.00 \\
4.39 \pm 0.55\end{array}$ \\
\hline Coagulase negative staphylococci & $\begin{array}{l}+2 \\
+7\end{array}$ & - & $\begin{array}{c}- \\
2.00 \pm 0.00\end{array}$ & - & $\begin{array}{c}2.69 \pm 0.30 \\
-\end{array}$ & $\begin{array}{l}2.39 \pm 0.12 \\
3.19 \pm 0.27\end{array}$ \\
\hline
\end{tabular}

TVC, total viable count; LAB, Lactobacillus spp.; CNS, coagulase negative staphylococci. *Means in rows with different capital case letters (A-D) are significantly different (P<0.01); ${ }^{\circ}$ means within columns with different lower case letters ( $\mathrm{x}$ and $y$ ) are significantly different $(\mathrm{P}<0.01 ; \mathrm{P}<0.5)$; ${ }^{\sharp}$ not detected. 
stored at $+7^{\circ} \mathrm{C}$, higher levels were recorded during all the storage time and a progressive increase and final counts $>5$ log were recorded. Q2.2 samples showed higher levels with storage, particularly at $+2^{\circ} \mathrm{C}$, and an increase at both temperature was detected, with final levels of $c a$. 4 and $5 \log$, respectively in samples stored at +2 and $+7^{\circ} \mathrm{C}$.

In Q1 and Q2.1 samples T0 mean levels of LAB were $c a$. 2 log. A rise was detected during storage at both temperatures and final counts of $4 \log$ were attained. A similar trend was noticed in Q2.2 samples, but with slightly lower final levels (ca. $3 \mathrm{log}$ ).

Pseudomonas spp. in Q1 and Q2.1 showed a significant $(\mathrm{P}<0.01)$ rise during storage irrespective of the temperature and represented the dominant bacterial species at the end of storage with mean levels $>7 \log$ in samples stored at $+2^{\circ} \mathrm{C}$ and $>8 \log$ in those at $+7^{\circ} \mathrm{C}$. Q2.2 samples showed a similar trend with a progressive increase throughout the entire storage period, irrespective of temperatures with final levels $>7$ log.

CNS constituted part of the microflora of Q1 and Q2.1 samples and showed a progressive increase during storage at both temperatures, attaining final levels of $c a$. 6 log. In Q2.2 samples, mean counts were also high with a progressive increase at both temperatures and final levels of 6 and $7 \log$ in samples stored at +2 and at $+7^{\circ} \mathrm{C}$, respectively.

Yeasts and moulds: mean counts were also high with a progressive increase irrespective of temperature. Moulds mean levels were higher in samples stored at $+2^{\circ} \mathrm{C}$ than in samples stored at $+7^{\circ} \mathrm{C}$ in which were isolated only until T7. Mean counts and trends were similar to those detected in analogue products air-packaged without rosemary.

$B$. thermosphacta and L. monocytogenes were not detected in any of the samples. Salmonella spp. was isolated in 12 out of 36 samples of Q1 and Q2.1 samples (33\%) and in 6 out of 18 Q2.2 samples (33\%). Salmonella was isolated throughout the storage time, and at both temperatures. Two Salmonella serotypes were detected: $S$. Typhimurium monophasic variant 1,4,[5],12:i:- and $S$. Kentucky. The prevalence of $S$.Typhimurium monophasic variant 1,4,[5],12:i:- was $60 \%$ (6/10) in Q1 and Q2.1 samples, and 80\% (4/5) in Q2.2 samples. The prevalence of $S$. Kentucky was 40\% (4/10) in Q1 samples and 20\% (1/5) in Q2.2 samples. Phage typing of $S$. Typhimurium isolates resulted into 3 different phage types: in Q1 and Q2.1 samples DT7a $(83 \%, 5 / 6)$ and DT20a (17\%, 1/6), in Q2.2 samples U311 (75\%, $3 / 4)$ and DT7a $(25 \%, 1 / 4)$ were detected.

\section{Precooked quails (Q3)}

TVC mean values were low at the beginning of storage (ca. $2 \log$ ). Mean counts of samples stored at $+2^{\circ} \mathrm{C}$ showed an irregular trend with significant changes $(\mathrm{P}<0.01)$ during storage and attained final levels $>5 \mathrm{log}$, while those of samples stored at $+7^{\circ} \mathrm{C}$ increased gradually $(\mathrm{P}<0.01)$ with higher final levels $(>6 \log )$.

Enterobacteriaceae were only detected in samples stored at $+7^{\circ} \mathrm{C}$ at the end of the experiment (ca. $2 \log )$.

Pseudomonas spp. in samples stored at $+2{ }^{\circ} \mathrm{C}$ was isolated after 7 days of storage with mean levels $>4 \log$ that increased to 5 at the end of the storage. A similar trend was noticed in samples stored at $+7^{\circ} \mathrm{C}$.

CNS mean levels remained low during storage at both temperatures ( $c a .2 \log$ ). LAB, Brochotrix thermosphacta, Enterococcus spp., yeasts, moulds, solphite-reducing anaerobes, Clostridium perfringens, mesophilic aerobic sporulating bacteria, Listeria monocytogenes and Salmonella spp. were not detected in any of the samples.

\section{Discussion}

For TVC, the value of $7 \log \mathrm{CFU} / \mathrm{g}$ is considered the upper acceptability limit for fresh poultry meat as defined the by International Commission on Microbiological Specifications for Foods (ICMSF, 1998). In samples Q1 and Q2.1 this limit was reached between $\mathrm{T} 9$ and T14 under storage at $+2^{\circ} \mathrm{C}$, and between T7 and T9 under storage at $+7^{\circ}$. In Q2.2 samples such limit was reached earlier, between T3 and T7, irrespective of the temperature. Therefore, rosemary seems to influence the shelf-life of fresh quails packaged in air, even if no statistical difference could be attributed to its presence. TVC levels could be due to the initial microbial load and also to the contamination during preparation. Pseudomonas, CNS and, to a lesser degree, LAB constituted part of the microflora of fresh quails. The growth of yeasts and moulds was observed in fresh quails at $\mathrm{T} 0$ and, particularly yeasts attained high levels ( $>4 \log$ at both temperatures of storage) starting from T7. These results are in agreement with those obtained in similar studies for various chicken products (Ismail et al., 2000, Patsias et al., 2006). Considering the organoleptic characteristics and the microbiological results, a shelflife of 7 days could be appropriate of fresh quails packaged in air and could be improved by reducing the initial microbial load.

Salmonella prevalence in fresh quails airpackaged with and without rosemary was higher (33\%) than in other studies and can represent a risk for public health. This can be caused by the presence of Salmonella at farm level, confirmed by the results of official (on faecal and dust samples) and on-check food business operator (FBO) controls (data not showed). As prevention measures, the FBO will implement vaccination and improve clea- ning and disinfection procedures. It is important to highlight that the identified serotypes, $S$. Typhimurium monophasic variant and $S$. Kentucky, are among the 10 most frequent serovars isolated from confirmed cases of human salmonellosis in 2010-2011 (EFSA, 2013).

\section{Conclusions}

As expected, in precooked quails packaged under vacuum, TVC levels were lower and did not reach the above mentioned limit, not even at the end of storage. However, mean counts $>5 \log$ were reached in samples stored at $+2^{\circ} \mathrm{C}$ at T14 and at $+7^{\circ} \mathrm{C}$ at T9. This could be attributed to a post-cooking cross-contamination. In a related study, Patsias et al. (2006) reported similarly high initial TVC microbial load ( $c a .4$ $\log$ ) in a chilled pre-cooked chicken product.

Vacuum packaging changes the microflora but does not inhibit bacterial growth. During spoilage, the species that predominate are those with the shortest generation times under the storage conditions. For example, LAB do not normally compete well, because of their longer generation times (Linton et al., 2004). In Q3 samples, Pseudomonas has been isolated starting from $\mathrm{T} 7$ and reached quite high levels ( $>4 \log$ ), irrespective of the temperature of storage. Sawaya et al. (1993) reported that Pseudomonas grew slowly in vacuum packs but did not reach the high numbers achieved under aerobic conditions. For precooked vacuum packaged quails a shelf life of 9 days could be considered acceptable.

\section{References}

EFSA, 2013. The European Union summary report on trends and sources of zoonoses, zoonotic agents and food-borne outbreaks in 2011. EFSA Journal 11:3129. Available from: http://www.efsa.europa.eu/ it/efsajournal/doc/3129.pdf

ICMSF, 1998. Poultry and poultry products. In: Roberts TA, Pitt JI, Farkas J, Grau FH, Microorganisms in foods, 6. Microbial ecology of food commodities. Blackie Academic and Professional Publ., London, UK, pp 75-129.

ISO, 1996. Microbiology of food and animal feeding stuffs. Horizontal method for the detection and enumeration of Listeria monocytogenes. Part 1: detection method. ISO Norm 11290-1:1996. International Standardization Organization ed., Geneva, Switzerland.

ISO, 1998. Microbiology of food and animal feeding stuffs. Horizontal method for the 
detection and enumeration of Listeria monocytogenes. Part 2: enumeration method. ISO Norm 11290-2:1998. International Standardization Organization ed., Geneva, Switzerland.

ISO, 2001. Microbiology of food and animal feeding stuffs. Horizontal method for the enumeration of beta-glucuronidase-positive Escherichia coli. Part 2: colony-count technique at 44 degrees $\mathrm{C}$ using 5 -bromo4-chloro-3-indolyl beta-D-glucuronide. ISO Norm 16649-2:2001. International Standardization Organization ed., Geneva, Switzerland.

ISO, 2002. Microbiology of food and animal feeding stuffs. Horizontal method for the detection of Salmonella spp. ISO Norm 6579:2002. International Standardization Organization ed., Geneva, Switzerland.

ISO, 2004. Microbiology of food and animal feeding stuffs. Horizontal methods for the detection and enumeration of Enterobacteriaceae. Part 2: colony-count method. ISO Norm 21528-2:2004. International Standardization Organization ed., Geneva, Switzerland.

ISO, 2013. Microbiology of the food chain. Horizontal method for the enumeration of microorganisms. Part 2: colony count at 30 degrees $\mathrm{C}$ by the surface plating tech- nique. ISO Norm 4833-2:2013. International Standardization Organization ed., Geneva, Switzerland.

Ismail SAS, Deak T, Abd El-Rahman HA, Yassien MAM, Beuchat LR, 2000. Presence and changes in populations of yeasts on raw and processed poultry products stored at refrigeration temperature. Int $\mathrm{J}$ Food Microbiol 62:113-21.

Khanjari A, Karabagias KI, Kontominas MG, 2013. Combined effect of N,O-carboxymethyl chitosan and oregano essential oil to extend shelf life and control Listeria monocytogenes in raw chicken meat fillets. Food Sci Technol-LEB 53:94-9.

Linton M, McClements JMJ, Patterson MF, 2004. Changes in the microbiological quality of vacuum-packaged, minced chicken treated with high hydrostatic pressure. Innov Food Sci Emerg 5:151-9.

Mexis SF, Chouliara E, Kontominas MG, 2012. Shelf-life extension of ground chicken meat using an oxygen absorber and a citrus extract. Food Sci Technol-LEB 49:21-7.

Patsias A, Badeka AV, Savvaidis IN, Kontominas MG, 2008. Combined effect of freeze chilling and MAP on quality parameters of raw chicken fillets. Food Microbiol 25:575-81.

Patsias A, Chouliara I, Badeka A, Savvaidis IN,
Kontominas MG, 2006. Shelf-life of precooked chicken product stored in air and under modified atmospheres: microbiological, chemical, sensory attributes. Food Microbiol 23:423-9.

Rojas M, González I, Fajardo V, Martín I, Hernández PE, García T, Martín R, 2009. Authentication of meats from quail (Coturnix coturnix), pheasant(Phasianus colchicus), partridge (Alectoris spp.), and guinea fowl (Numida meleagris) using polymerase chain reaction targeting specific sequences from the mitochondrial 12S rRNA gene. Food Control 10:896-902.

Sawaya WN, Abu-Ruwaida, Hussain AJ, Khalafawi MS, Dashti BH, 1993. Shelf-life of vacuum-packaged eviscerated broiler carcasses under simulated market storage conditions. J Food Safety 13:305-21.

Scarano C, Cannas G, Mureddu A, De Santis EPL, Mazzette R, Cosseddu AM, 2004. [Contaminazione microbica di quaglie (Coturnix coturnix) alla macellazione e valutazione della shelf-life]. [Proc. in Italian]. Proceedings of the 24th National Congress of Veterinary Food Hygienists, 2004 June 4-6, Santuario di Vicoforte (CN), Italy, pp 369-374. 